International Journal of Instruction e-ISSN: 1308-1470 • www.e-iji.net

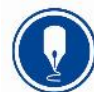

January $2022 \bullet$ Vol.15, No.1

p-ISSN: 1694-609X

pp. $365-380$

Article submission code: 20210301094735
Received: 01/03/2021

Revision: 29/06/2021
Accepted: $24 / 07 / 2021$

OnlineFirst: 24/10/2021

\title{
Contextualization of Inclusive Education: Education for Children with Disabilities in Myanmar
}

\section{Yoshiko Tonegawa}

Asst. Prof., Waseda University, Japan, ytonegawa@waseda.jp

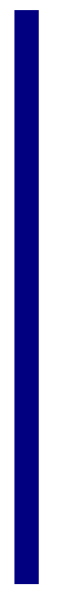

\begin{abstract}
Inclusive education is regarded as one of the global agendas of education; in recent years, many countries have implemented an inclusive education policy. This case study aimed to examine the actual practice of inclusive education among children with disabilities today. More specifically, this study analyzed the case of inclusive education for children with visual impairment in Yangon, Myanmar. In Yangon, "a limited inclusive education in phase" allows children with visual impairment to experience both special and regular schools. This study's findings revealed that the special schools had met the students' needs with life-skills courses, supplementary study time, and a safe environment. However, there were some challenges, including a lack of communication between the special and regular schools and inadequate bonding between students with and without visual impairment. However, it also suggests the importance of addressing the wider range of needs of students with disabilities for inclusive education. This case in Yangon is considered as a type of inclusive education which utilizes their resources to fit their context.
\end{abstract}

Keywords: inclusive education, children with disabilities, special education, special schools, children with visual impairment, Myanmar, special needs education

\section{INTRODUCTION}

Inclusive education for children with disabilities has attracted international attention in recent years, and the policy has been introduced in many countries. Especially, since Goal 4 of the Sustainable Development Goals is to "[e]nsure inclusive and equitable quality education and promote lifelong learning opportunities for all" (UN, n.d.), inclusive education has become one of the global agendas in education.

The term inclusive education was proposed by the Salamanca Declaration, adopted at the World Conference on Education for Special Needs, held by UNESCO in 1994. The Article 2 of the Declaration states the basic idea of inclusive education: "[e]very child has a fundamental right to education and must be given the opportunity to achieve and maintain an acceptable level of learning." It also includes, "those with special educational needs must have access to regular schools which should accommodate them within a child-centered pedagogy capable of meeting these needs" (UNESCO \& MoES

Citation: Tonegawa, Y. (2022). Contextualization of inclusive education: Education for children with disabilities in Myanmar. International Journal of Instruction, 15(1), 365-380. https://doi.org/10.29333/iji.2022.15121a 
1994: viii). Furthermore, The Convention on the Rights of Persons with Disabilities (CRPD), adopted by the UN General Assembly in 2006, states that the State Parties shall ensure "inclusive education systems at all levels" and that "[p]ersons with disabilities can access an inclusive, quality and free primary education and secondary education on an equal basis with others in the communities in which they live" (UN 2006: 14-15).

Although there are various definitions for inclusive education, it can be defined as quality education meeting every child's educational needs based on these international agreements. Especially, the consideration for educational needs has been valued. Moreover, some aspects of the international consensus documents above emphasize educating all children in the same place at regular schools in their area of residence. For instance, according to Ikhwanudin and Suryadi (2018: 309), "[i]nclusive education is an education service system that includes children with special needs learning together with their peers in the regular school."

The Republic of the Union of Myanmar (hereinafter, Myanmar) has also been focusing on education for children with disabilities in recent years. After ratifying CRPD in 2011, the Myanmar government enacted the Law on the Rights of Persons with Disabilities in 2015, which states that "[e]very person with disabilities shall have the right to access the education on equal basis for others" (Republic of the Union of Myanmar, 2015b: 7). In 2019, the Ministry of Education held a seminar on inclusive education focusing on children with disabilities, and the Minister of Education gave a speech on the importance of inclusive education ("MoE organizes disability-inclusive education seminar", 2019). However, inclusive education in Myanmar has not been studied sufficiently. Therefore, this study aimed to examine the actual practice of inclusive education for children with disabilities in the current modality where inclusive education is regarded as one of the global agendas in education. More specifically this study analyzes the case of education for children with visual impairment in Myanmar.

\section{Literature Review: Place for Inclusive Education for Children with Disabilities}

According to the existing literature, one of the most significant aspects of education for children with disabilities in regular schools is the acquisition of non-cognitive skills, especially social skills and communication skills. For instance, the existing research has shown that when students with disabilities are educated together with non-disabled students in the same classroom, they interact with each other and develop communication skills (e.g., Boer et al., 2010; Scheepstra et al., 1999). Furthermore, it is also expected to lead to future participation of children with disabilities in society (Boer, et al., 2010; Scheepstra et al., 1999). In the study conducted by Tonegawa (2019), teachers perceived that communication skills were strengthened not only for students with disabilities but also for students without disabilities. Therefore, an inclusive education system can be interpreted as contributing to the formation of an inclusive society (e.g., Ainscow, 2005). Lipsky \& Gartner (1999) also argue that inclusive education is important in building a democratic society. Another study reported that the segregation of children with disabilities in special schools leads to marginalization (e.g., Jenkinson, 1997). 
There is also much debate about the significance of education in special schools. First, special schools allow students to acquire specialized skills according to their disabilities, including Braille, sign language, and mobility training by using white cane. It is also asserted that students can meet role models with the same disabilities in special schools, which can enhance their self-esteem as a person with disabilities (Jenkinson, 1997). Some studies have reported the teasing and bullying of students with disabilities in regular classes by students without disabilities; this suggests that a special school environment is safer and more desirable for students with disabilities (UNESCO, 2009; UNICEF, 2016). Warnock \& Norwich (2010) also argue that "[w] hat is needed is that all children should be included within a common educational project, not that they should be included under one roof." The World Federation of the Deaf expressed also concern about inclusive education-especially, place of children with hearing impairment in regular schools, and called for the right to choose the place of education (WFD, 2008).

There are also arguments that what occurs in the educational setting is more important than its place (e.g., Jenkinson, 1997). However, drawing on international consensus documents, many countries promote the concept that all children should be educated in the same classroom in regular schools. Based on the findings by Ochiai \& Shimada (2010), there are three categories of education for children with disabilities based on the place for education: (1) the one-track system in which all children study in regular classes; (2) the dual-track system, in which education is completely divided between regular schools and special schools for children with disabilities; and (3) the multipletrack system, which incorporates both the one-track and the dual-track systems. Although most countries are applying the multiple-track system, it is often debated whether the system is more unified or dualistic in place.

According to the UN (2019), 44\% of the member states reported that students with and without disabilities are educated in the same classrooms, but there was no indication of whether the educational needs of the students are considered in the classroom. Since inclusive education has evolved as a global agenda, in many low-income countries, students with disabilities are accepted in regular schools without consideration for their educational needs. For instance, in Malawi, special schools have been closed and special schools have been shifted to regular schools (Kawaguchi \& Kuroda, 2013). The onetrack system for inclusive education is promoted without preparation in many countries.

\section{Education For Children with Disabilities in Myanmar}

\section{Education for children with disabilities}

In Myanmar, after a long period of military rule, the Thein Sein administration brought democracy to the country in 2011, accompanied by large-scale educational reforms and the promulgation of a new National Education Law in 2014 (Tanaka, 2017). Based on The Law Amending the National Education Law enacted the following year in 2015, a new school system with one year for kindergarten, five years of primary education (Grade 1-5), four years of lower secondary education (Grade 6-9), and three years of upper secondary education (Grade 10-12), was introduced. 
According to the 2019 survey conducted by the Ministry of Population, $12.8 \%$ of the population have one of the six disabilities: $6.3 \%$ have visual impairment; $2.4 \%$, hearing impairment; 5.4\%, difficulties walking; 4.4\%, difficulties in remembering/ concentrating; $1.9 \%$, difficulties in self-care; and $1.6 \%$, difficulties in communication (DoP, 2020: 93).

The objectives of the Law on the Rights of Persons with Disabilities, enacted in 2015, say that "[e]very person with disabilities shall have the right to access the education on equal basis with others" and "not to be rejected from the school enrolment due to the disability" (Republic of the Union of Myanmar, 2015b: 7, 9). From basic education to higher education, the law clearly states the need to develop educational support systems.

Although the National Education Law of 2014 included the promotion of education for children with disabilities (Republic of the Union of Myanmar, 2014), there was no mention of inclusive education; it was included in The Law Amending the National Education Law of 2015. It explicitly states that "inclusive education means programme which creates opportunities to access the education.... for those, including the disabled, who are not available to access the education for various reasons" (Republic of the Union of Myanmar, 2015a: 2).

\section{Special schools for children with disabilities}

Public special schools are under the jurisdiction of the Department of Social Welfare (DSW) of Myanmar's Ministry of Social Welfare, Relief and Resettlement. In addition, there are special schools run by non-profit organizations such as NGOs and religious groups (UNESCO, 2014). There are a total of six public special schools for children with disabilities including two for children with visual impairment. Most of these schools are concentrated in Yangon and Mandalay regions (DSW, n.d.). The exact number of special schools run by non-profit organizations is not known.

According to the Ministry of Education in 2019, children with disabilities are enrolled in $14.72 \%$ of all regular schools from primary to secondary education (Muta, 2020). The statistics indicating education for children with disabilities is limited in Myanmar. Although the 2014 census by the Department of Population include education of children with disabilities, the type of school is not specified. It is assumed to comprise all kinds of schools including regular schools, special schools, monastery schools, and community schools. Based on the data which include all type of schools, $46.1 \%$ of the children with disabilities aged 5-9 years and $48.6 \%$ of the children with disabilities aged 10-13 years are enrolled in schools (DoP et al., 2017: 50). About 45.4\% of the children with disabilities aged 5-9 years and $31.4 \%$ of the children with disabilities aged 10-13 years have never attended school (DoP et al., 2017: 156). The enrollment rate of children with disabilities is clearly low compared to the net enrollment rate in formal education in Myanmar as a whole, where $98.5 \%$ is in formal primary education and $79.2 \%$ in formal lower secondary education (UIS, n.d.). In Myanmar, school enrollment for children with disabilities is still limited. 


\section{Secondary Education for Children with Visual Impairment in Yangon}

\section{Research site and data collection method}

According to a 2019 survey by the Department of Population, Yangon Region, where the city of Yangon is located, has the largest population in the country, with approximately 7.21 million residents, of which $12.4 \%$ have disabilities (DoP, 2020: 94). Of the disabilities covered by the survey, the Yangon Region has the highest number of visually impaired people, at 6.5\% (DoP, 2020: 94). According to data from the Ministry of Education in 2017, 1,310 children with disabilities were enrolled in regular schools in Yangon Region.

In Yangon Region, there is an educational system in which children with either visual or hearing impairment are allowed to be enrolled in both special schools and regular schools. These special schools include two special schools for children with visual impairment and one special school for children with hearing impairment. According to the Yangon Region Education Office, there were 155 children with disabilities from primary school to upper secondary education in this educational system in 2018. This study focused on this educational system and selected two special schools for children with visual impairment as a case study since the number of the people with visual impairment is the highest in Yangon Region and Myanmar as a whole. This study selected a public special school (Special School A) and a special school run by a Christian non-profit organization (Special School B), and two public regular schools (Schools C and D) connected to each of these special schools in Yangon City.

\section{METHOD}

This research used case study methods, qualitative research designs that emphasize the holistic interpretation of phenomena (Merriam, 1998). This study's data collection methods included semi-structured individual interviews, focus group discussion (FGD), school observations, and document reviews. The main field research was conducted for two weeks in February 2019 in Yangon, Myanmar. The major informants comprised students with visual impairment (six enrolled in both Special School A and School C, and six enrolled in both Special School B and School D), parents of visually impaired students enrolled in the target schools (nine in total), teachers (18 in total), principals (four in total), officers of Yangon Region Education Office and a former director of the DSW. The focus group discussion was conducted with groups of teachers only; each group consisted of three teachers. The rest of the subjects participated in semi-structured individual interviews.

\section{The target schools-two special schools for children with visual impairment and two regular schools}

Special School A, which is a public special school for children with visual impairment, was established in 1914 by Christian missionaries and transferred to the Ministry of Social Welfare, Relief and Resettlement in 1963. Special schools are under the jurisdiction of DSW of the Ministry of Social Welfare, Relief and Rehabilitation, not the 
Ministry of Education. Therefore, all the teachers and staff of Special School A are civil servants of the DSW. There are 120 students enrolled (Table 1), and the school is managed by a principal, two vice principals, and 15 teachers (including the visually impaired) who teach from kindergarten to the fifth grade of primary education. In addition to the budget from the government, the school receives support from outside sources, and does not charge tuition or dormitory fees.

Table 1

Number of students enrolled in Special School A

\begin{tabular}{llll}
\hline Education level and place for education & Male & Female & Total \\
\hline Kindergarten offered within Special School A & 15 & 12 & 27 \\
\hline Primary education offered within Special School A: Grade 1-5 & 9 & 17 & 26 \\
\hline Lower secondary education offered in School C: Grade 6-9 & 19 & 12 & 31 \\
\hline Upper secondary education offered in other school: Grade 10-11 & 9 & 3 & 12 \\
\hline Higher education offered in universities and graduate schools & 16 & 8 & 24 \\
\hline Total & 68 & 52 & 120
\end{tabular}

Source: Data provided by Yangon Region Education Office \& Special School A in February 2019.

Special School B was established in 1975 by a Christian organization that supports the visually impaired and was initially intended for adults with visual impairment. In 1979, the school became managed by a church organization in Yangon and began to receive support from Christian organizations outside the country. DSW provides rice, clothes, and salary for a caregiver. Half of the teaching staff are visually impaired, and many are graduates of Special School B. The school accepts children from the age of five, but in some cases, it also accepts children under the age. The school has 121 students (Table 2) and is managed by a principal and 21 teachers who teach from kindergarten to the fifth grade. The school charges a monthly fee of 2,400 kyats per student, depending on the family situation.

Table 2

Number of students enrolled in Special School B

\begin{tabular}{llll}
\hline Education level and place for education & Male & Female & Total \\
\hline Kindergarten offered within Special School B & 4 & 5 & 9 \\
\hline Primary education offered within Special School B: Grade 1-5 & 32 & 26 & 58 \\
\hline Lower secondary education offered in School D: Grade 6-9 & 13 & 14 & 27 \\
\hline Upper secondary education offered in other school: Grade 10-11 & 4 & 4 & 8 \\
\hline Higher education offered in universities and graduate schools & 9 & 10 & 19 \\
\hline Total & 62 & 59 & 121 \\
\hline Sour
\end{tabular}

Source: Data provided by Yangon Region Education Office \& Special School B in February 2019.

Both Special Schools A and B have dormitories attached to them, and many students come from far away to attend both schools. Although Special Schools A and B have different governing bodies, Special School B maintained a good relationship with DSW, and a similar school system was adopted. In both special schools, children of school age (5 years old and above) are simultaneously registered in public regular schools although they do not receive education in the regular schools. They receive their primary 
education (Grade 1-5) at the Special School and take the final examination for primary education (at the end of Grade 5) at the public regular school where they are registered. From the lower secondary education, they receive their education at the regular school where they are registered since their school age.

School C, a regular school connected to Special School A, was established in 1955 and has 373 students in total (FY 2018). According to the principal, students from Special School A began taking the final exam for primary education at School C in 1994; they were not registered at School C. Since 2000, when they reached school age, they have been registered at School C; they receive education in Special School A. In 2004, students of Special School A started to receive lower secondary education at School C together with non-disabled students. Thirty-two students of Special School A receive lower secondary education at School C (Table 3). The school has a principal and 14 teachers, and six of the nine staff members in charge of lower secondary education.

Table 3

Number of the students in School C (lower secondary education, FY 2018)

\begin{tabular}{llll}
\hline \multirow{2}{*}{ Grade } & \multicolumn{4}{l}{ Number of students (Number of students with visual impairment) } \\
\cline { 2 - 4 } & Male & Female & Total \\
\hline 6 & $37(10)$ & $14(1)$ & $51(11)$ \\
\hline 7 & $36(7)$ & $16(4)$ & $52(11)$ \\
\hline 8 & $30(1)$ & $23(6)$ & $53(7)$ \\
\hline 9 & $13(1)$ & $22(2)$ & $35(3)$ \\
\hline Total & $116(19)$ & $75(13)$ & $191(32)$ \\
\hline
\end{tabular}

Source: Data provided by Yangon Region Education Office and School C in February 2019.

School D, a regular school connected to Special School B, was established around 1965 and has a total enrollment of 779 students (FY 2018). According to the principal, students from Special School B started receiving education in the same classrooms as students without disabilities in School D in 2002. Until then, they only took the final exam for primary education at School D. In total, 26 students receive education in School D (Table 4). Currently, there is a principal and 20 teachers (14 of whom are teachers for secondary education).

Table 4

The number of the students in School D (lower secondary education, FY 2018)

\begin{tabular}{llll}
\hline \multirow{2}{*}{ Grade } & \multicolumn{3}{l}{ Number of students (Number of students with visual impairment) } \\
\cline { 2 - 4 } & Male & Female & Total \\
\hline 6 & $49(3)$ & $55(4)$ & $104(7)$ \\
\hline 7 & $66(1)$ & $61(3)$ & $127(4)$ \\
\hline 8 & $76(5)$ & $56(4)$ & $132(9)$ \\
\hline 9 & $41(3)$ & $38(3)$ & $79(6)$ \\
\hline Total & $232(12)$ & $210(14)$ & $442(26)$ \\
\hline
\end{tabular}

Source: Data provided by Yangon Region Education Office and School D in February 2019.

Both Schools C and D accommodate children from primary education to the ninth grade of lower secondary education and two classes for each grade in lower secondary education. The size of one class is 13 to 25 students for School C and 39 to 52 students 
for School D. Only one class, per grade, has students with visual impairment. One of the major considerations for students with visual impairment in Schools C and D is peer support. Peer support refers to students without disabilities providing support to students with disabilities. One student without disability assists a visually impaired student of the same class by verbally telling what the teacher has written on the board. Peer students without disabilities are assigned by the teacher in shifts of one day or one week.

As mentioned above, according to the principals, students with visual impairment in Schools C and D started to receive education in regular schools in 2004 and 2002, respectively. This is after the Salamanca Declaration but before the adoption of the CRPD. It is not clear to what extent inclusive education as a global agenda has had an impact to this educational system in Yangon. However, the principal of School D referred to the students with visual impairment who were educated in School D as "IE (inclusive education) students," and the principals and teachers of all four schools recognized the current system in which students of Special Schools A and B are educated in regular schools from lower secondary education as "inclusive education."

\section{FINDINGS}

\section{"Limited Inclusive Education in Phase" In Yangon}

\section{Perceptions of "limited inclusive education in phases" in Yangon City}

As seen from the situation at Special Schools A and B described in the previous section, children with visual impairment in Yangon receive their primary education at special schools in the first phase, and from secondary education onwards, they are educated together with non-disabled students in the same classrooms at regular schools in the second phase. Schools C and D accept only visually impaired students enrolled in the connected Special Schools A and B; they do not accept a wide range of visually impaired students. Also, they do not actively accept children with types of disabilities other than visual impairment. This educational system can be called as the "limited inclusive education in phase," which is close to dual-track system since special schools play an important role for students with visual impairment as explained later.

\section{Significance of education at special schools for students with visual impairment}

The informants in this study had a positive impression about this education system: they uniformly emphasized the importance of special schools.

First, special schools provide Braille education, which is a specialized ability to meet the unique educational needs of the visually impaired, as was noted as the significance of special schools in the existing literature. Furthermore, since the students with visual impairment receive their primary education in a special school, they can learn their lessons as well as follow instructions in class using Braille. Also, the principal and teachers of the regular school, as well as students with visual impairment stressed that the special schools have teachers and staff who are visually impaired and have a good understanding of how to teach visually impaired students (e.g., Student No. 3 at Special School B). 
Besides, training for life skills including eating, toileting, and walking with a white cane at the special school, was also valued by the informants (e.g., Principal at Special school B). Without these life skills, it would be difficult for students with visual impairment to have a smooth school life in regular schools.

Furthermore, the value that was placed on meeting the educational needs of visually impaired students was supplementary study time provided at both Special Schools A and B. During this study time, the visually impaired students worked on their homework assigned at the regular school and review what they have learned. They could ask the teachers at the special schools for clarification, and students with visual impairment can also teach each other. The special schools complement education at the regular school. The students with visual impairment and their parents also expressed that the special school helps them with their study at the regular school (Student No. 5 at Special School B; Parents No. 1 of students at Special School B). Moreover, the special schools offered training for computer skills. The visually impaired students and their parents also appreciated computer skills as practical skills (Students No. $3 \& 6$ at Special School A; Parents No. $2 \& 3$ of students at Special School B).

Lastly, most of the students addressed mental satisfaction. Many visually impaired students mentioned the sense of security that comes with the presence of visually impaired students and teachers at a special school. This allows for mutual understanding and the ability to spend time freely with other visually impaired people without hesitation (e.g., Student No. 1 at Special School A, Student No. 4 at Special School B). The students emphasized that the special schools understand the needs of visually impaired students well (e.g., Student No. 6 at Special School B). Parents of visually impaired students also had a sense of security that the school would take good care of the visually impaired students (e.g., Parent No. 1 of a student at Special School B). This sense of mental fulfillment is also presumably related to the bullying and teasing most of the subject students with visual impairment experienced in the regular school. For instance, one student said, "sometimes students without disabilities say bad things about me, and students without disabilities hit me and run away because students with visual impairment can't see (Student No. 5 of Special School B)." The visually impaired students can share feelings and experiences they have in regular schools with other students and can discuss them with teachers and staff of the special schools.

In this way, the special schools clearly function as a place to meet a wide range of needs of students with disabilities, including not only educational needs but also life skills, practical education, and mental fulfillment. This also indicates that there are other needs to be fulfilled than educational needs for students with disabilities although the educational needs are often internationally emphasized.

Significance of education in regular schools for students with visual impairment

Many informants also emphasized the importance of regular schools and supported this educational system "inclusive education in phase." The informants gave two main reasons for their support: the acquisition of non-cognitive skills by students with visual impairment and the impact on students without disabilities. 
Firstly, in regular school, students with visual impairment can gain social skills. Boer et al. (2010) and Scheepstra et al. (1999) also emphasized socialization. Tonegawa (2019) found that, in Ethiopia, many teachers, parents of children with disabilities, and parents of children without disabilities believed that teaching children with and without disabilities side-by-side helped both enhance their social and communication skills. Although the visually impaired students in this study in Myanmar complained of being bullied by children without disabilities, they also argued that regular school was important because it helped them cultivate social skills and communication skills for the future. The teachers as well as parents valued communication among students as an advantage of receiving education in regular schools (Principal of School D; $1^{\text {st }}$ FGD of teachers at Special School B; $2^{\text {nd }}$ FGD of teachers at Regular School D; Parent No. 2 of a student at Special School B). The principal of Special School B also commented that the current life at the regular school would be a good practice for the visually impaired students to build good relationships with non-disabled students when they become college students.

Secondly, students without disabilities are expected to understand disabilities and people with disabilities, and have empathy for students with disabilities. This point was emphasized by the principal, teachers, and parents except for students with visual impairment (e.g., Parents No. $2 \& 3$ of students at Special School B). The principal of Special School B and the teachers of Schools C and D mentioned that the advantage of having students with and without disabilities educated together is that they can learn about each other. Especially, the students without disabilities can learn about disabilities and how to respond to and help people with disabilities. This point also coincides with the improvement of communication skills of students without disabilities in the previous study (e.g., Boer et al., 2010; Scheepstra et al., 1999).

At Schools C and D, without any instruction from the teachers, non-disabled students helped students with disabilities go to and from the classroom. When a visually impaired student arrived at school in the morning, students without disabilities who came to school before them would pick them up at the gate and accompany them to the classroom. Teachers at School C said that mutual understanding allowed them to feel closer to each other and to treat each other with love ( $2^{\text {nd }}$ FGD of teachers in School C). Although there was teasing and bullying, students without disabilities helped students with visual impairment to go to and from the classroom. This indicates that students without disabilities understand the needs of the students with visual impairment to some extent.

\section{Limitations of limited inclusive education in phase in Yangon City}

The previous section addressed why the informants supported "limited inclusive education in phases," which allows the students with disabilities to experience both a special school and a regular school. However, this study also found some limitations in this educational system.

\section{Relationship between special schools and regular schools}

First, there were no opportunities for the teachers and staff of the special school and the regular school to exchange information and consult each other, and there was a 
divergence in the relationship between the two schools. According to a teacher at Special School A, although teachers from the special schools and the regular schools sometimes meet each other at events, they do not exchange information or learn from each other about the education and school life of the students with visually impairment ( $1^{\text {st }}$ FGD of teachers at Special School A). There was not enough cooperation between the teachers in the special schools and the regular schools in this study's subject schools. Previous studies have reported that teachers at regular schools often face difficulties teaching children with and without disabilities together in one classroom (e.g., Rasmitadila et al., 2021; Tonegawa, 2019); the same was true for the teachers in our study. Rasmitadila et al.'s (2021) research in primary schools in Indonesia found that general and special teachers need to cooperate to provide education that meets the needs of children with disabilities.

As for the divergence between schools for the special and regular schools, it could be due to the fact that they are under different ministries: special schools are under the jurisdiction of DSW in the Ministry of Social Welfare, Relief and Resettlement, and regular schools are under the Ministry of Education. The existing study pointed that the education of children with disabilities in regular schools has been neglected since the Ministry of Education perceives that education of children with disabilities is the responsibility of DSW (ECDC \& VSO, 2015).

Furthermore, the dependency on the special school was observed among the teachers of the regular schools concerning the education of students with visual impairment. The teachers at the regular schools were aware of the fact that the visually impaired students found their learning from their teachers at the special school to be helpful during the study time. Thus, the regular school teachers felt that they could entrust the education of the visually impaired students to special school teachers. This mindset of the teachers may have influenced the lack of their consideration for the visually impaired students in the regular schools. On the other side, this relationship between the two schools can be interpreted as a "division of labor" or "collaboration" in which both schools do what they can do with limited resources: education about subjects at the regular schools and supplementary education using Braille at the special schools.

\section{Relationships between students with disabilities and students without disabilities}

The next limitation is about relationship between students with visual impairment and students without disabilities. As mentioned earlier, the significance of having visually impaired students studying in regular schools is that they can acquire non-cognitive skills, such as communication skills and social skills. However, according to this study, students with visual impairment are not always able to establish close relationships with non-disabled students. Out of the 12 visually impaired students, only one student addressed that s/he had a good friend without disability. The other students without disabilities were perceived as classmates, but not as close friends.

As per the informants, it is rare for students with and without disabilities to interact during recess, after school, or during the holidays. Students with visual impairment may have limited play options due to their disabilities. According to the principal of School 
D, students without disabilities are active outside during recess, while students with visual impairment spend their time separately indoors, playing with other students with visual impairment. The principal also commented that "students with visual impairment do not get along with non-disabled students and do not participate in school events with non-disabled students."

This situation may also be influenced by the age difference between students with and without visual impairment. Many students with visual impairment are older than their school age. Since the special schools are located far away from their homes, the children have to stay away from their families and hence, they are enrolled in special schools after they have reached a certain age. Therefore, they are often older than their peers without visual impairment. In this study, visually impaired students were also one to five years older than their school age. Students who are the same age may understand each other easily and communicate better than their younger classmates.

Other reasons might be that the children with visual impairment had already established friendships at the special schools before transferring to regular school or felt more comfortable with friends they had spent time with in the special schools' dormitories. In addition, bullying and teasing could have prevented the children with and without visual impairment from building close relationships with each other.

In the current "limited inclusive education in phase," students with and without visual impairment are limited to in-class interactions including peer support in the classroom. They have not started practicing collaboration with others, such as fostering sociability, caring for each other, and nurturing respect. In fact, a previous US study focusing on the parents of children with disabilities found that the parents were concerned about their children's isolation in regular schools' classrooms (Leyser \& Kirk, 2004). The visually impaired students in this study who had received their primary education at special schools also tended to remain separate-sometimes by choice-within the regular schools.

\section{Lack of awareness of educational opportunities for children with disabilities}

This study also found that people in Myanmar are not aware of the educational opportunities for people with disabilities and the existence of special schools. In order to receive this "limited inclusive education in phase," students need to enter a special school and receive primary education. However, about half of the subject parents, especially those living in rural areas, did not know about special schools. Some parents with visually impaired children had been refused admission by the regular schools in their area of residence. The parents had given up their children's schooling because they understood that children with visual impairment could not receive education at school. Some other parents had even given up schooling when they found that their children had visual impairment. Later, these parents, having found about the special schools by chance, through neighbors, relatives, or elder children who went to Yangon, enrolled their children in special schools. A few parents were informed by the regular school in their area about a special school, but this was rarely the case in rural areas far from the special schools. This indicated that parents often do not have information or 
understanding of schooling for children with disabilities; in other words, schooling for children with disabilities has not been fully recognized in Myanmar.

\section{DISCUSSIONS AND CONCLUSION}

As discussed above, the limited inclusive education for visually impaired students in Yangon has had both pros and cons. The findings of this study suggest that previous research has failed to adequately examine the following issues.

First, there is still no worldwide consensus on the superiority of the place for children with disabilities, either regular schools or special schools. This study examined the phased-in, limited inclusive education for visually impaired children that connects the two types of schools in Myanmar. This research found that the education system has created an inclusive education using the resources of existing special and regular schools. The special schools have been able to meet the visually impaired students' needs by teaching them life skills and practical skills, and providing supplementary study time and safe learning environments. This system works sufficiently well that Myanmar's experience could serve as a reference for countries promoting inclusive education.

However, this study also found that connecting special schools and regular schools in Yangon has not been without its challenges. Some issues include insufficient communication between teachers in special and regular schools, the regular school teachers' dependency on special school teachers' expertise, and isolationist tendencies between the students with and without disabilities. To begin addressing these issues, the DSW needs to develop training programs and policies that encourage mutual exchanges between special and regular school teachers. The schools also need to develop programs aimed at promoting inclusion, diversity, and camaraderie among all students. This might entail team-building activities and class discussions.

Second, this case suggests that the wider needs of children with disabilities have to be considered for the effective implementation of inclusive education. In the global agenda, educational needs for children with disabilities are often emphasized. This case study also underlines importance of their educational needs. Even though they were attending a regular school, the students with visual impairment were still receiving learning support at their special school, especially during supplementary study time. In addition, this study revealed that a wide range of needs of children with visual impairment, such as the acquisition of life skills and mental satisfaction, are crucial for children with disabilities to study with non-disabled children in regular schools. Also, it is necessary to focus on the perceptions of students without disabilities and their parents, who could not be included in the target population of this study. This is because inclusive education must meet the needs of students with disabilities as well as those without disabilities.

Reviewing the existing literature and examining this case of "a limited inclusive education in phase" in Yangon, the author does not deny the effectiveness of one-track inclusive education if all the needs of children with disabilities are fulfilled. However, in the current situation, many countries face difficulties in implementing this model. 
Therefore, each country, especially a low-income country, needs to understand their resources and utilize them effectively to fit their context.

As mentioned earlier, the Ministry of Education in Myanmar has emphasized the future expansion of one-track system for inclusive education, where students receive their education in regular schools. As Daniels \& Garner (2006: 22) describe inclusive education as a "dynamic process," the Ministry of Education and DSW need to be cooperative, careful, and creative to develop their model of inclusive education.

\section{AKNOWLEDGEMENTS}

This study was funded by a grant from the Sumitomo Mitsui Banking Corporation International Cooperation Foundation in 2018, JSPS KAKENHI Grant Number JP 19H00620, and a Waseda University Grant for Special Research Projects (Project number: 2018B-314, 2020C-340).

\section{REFERENCES}

Ainscow, M. (2005). Developing inclusive education systems: What are the levers for change? Journal of Educational Change, 6,109-124.

Boer, A., Pijl, S. J. \& Minnaert, A. (2010). Attitudes of parents towards inclusive education: A review of the literature. European Journal of Special Needs Education, 25(2), 165-181.

Daniels, H. \& Garner, P. (1999). World yearbook of education 1999: Inclusive education, London: Kogan Page.

Department of Population (DoP) (2015). The 2014 Myanmar population and housing census: Highlights of the main results. Census report volume 2-A. The Republic of the Union of Myanmar. Ministry of Immigration and Population.

Department of Population; Ministry of Labour \& Immigration and Population with technical assistance from UNFPA (2017). The 2014 Myanmar population and housing census: Thematic report on disability. Census Report Volume 4-K.

Department of Population (DoP) (2020). 2019 inter-censal survey: The Union report.

Department of Social Welfare (DSW) (n.d.). Caring service for persons with disability. The Republic of the Union of Myanmar, Ministry of Social Welfare, Relief and Resettlement. Retrieved 03 December, 2020 from https://www.dsw.gov.mm/en/node/2250

Eden Centre for Disabled Children (ECDC) \& Voluntary Service Overseas (VSO) (2015). A space to learn for children. Inclusive education and children with disabilities in Yangon, Myanmar. Yangon: Eden Centre for Disabled Children.

Ikhwanudin, T. \& Suryadi, D. (2018). How Students with Mathematics Learning Disabilities Understands Fraction: A Case from the Indonesian Inclusive School. International Journal of Instruction, 11(3), 309-326. 
Jenkinson, J. C. (1997). Mainstream or special? Educating students with disabilities NY: Taylor and Francis.

Kawaguchi, J. \& Kuroda, K. (2013). On the local adaptability of international education policy agenda: A case study of inclusive education policy in Malawi. Journal of Comparative Education, 46, 61-77.

Leyser, Y. \& Kirk, R. (2004). Evaluating Inclusion: an examination of parent views and factors influencing their perspectives, International Journal of Disability, Development and Education, 51(3), 271-285.

Lipsky, D. K. \& Gartner, A. (1999). Inclusive education: A requirement in democratic society. In H. Daniels \& P. Garner (Eds.), World yearbook of education 1999: Inclusive education. London: Kogan Page.

Merriam, S. B. (1998). Qualitative Research and Case Study Applications in Education: Revised and Expanded from Case Study Research. San Francisco: JosseyBass Publishers.

Muta, H. (2020). Myanmar renpou kyowakoku kisokyouikugakkou no gakusyuu kankyo ni kansuru genjyo bunseki [Analysis of the current situation of the learning environment of basic education schools in the Republic of the Union of Myanmar]. Tokyo: Japan International Cooperation Agency.

MoE organizes disability-inclusive education seminar in Nay Pyi Taw (25 July 2019) Global New Light of Myanmar. Retrieved 26 February, 2021 from https://www.gnlm.com.mm/moe-organizes-disability-inclusive-education-seminar-innay-pyi-taw/\#article-title

Ochiai, T. and Shimada, T. (2016). Kyosei Shakai wo Meguru Tokubetusienkyouiku narabini inclusive kyouiku no Arikata ni Kansuru ichikousatsu: Mary Warnock and Brahm Norwich (2010) no shiten kara [Study of the roles relevant to cohesive society on special needs education and inclusive education: From the viewpoints of Mary Warnock and Brahm Norwich (2010)]. Tokubetsu Shien Kyoiuku Jissen Center Kenkyu Kiyou [Research Bulletin of the Center for Special Education Practice], 14, 27-41.

Rasmitadila., Widyasari., Prasetyo, T., Rachmadtullah, R., Samsudin, A. \& Aliyyah, R. R. (2021). General teachers' experience of the brain's natural learning systems-based instructional approach in inclusive classroom. International Journal of Instruction, 14(3), 95-116.

Republic of the Union of Myanmar (2014). National Education Law. (Parliamentary Law No. 41).

Republic of the Union of Myanmar (2015a). The Law Amending the National Education Law. (The Pyidaungsu Hluttaw Law No. 38).

Republic of the Union of Myanmar (2015b). The Law on the Rights of Persons with Disabilities. (Pyidaungsu Hluttaw Law No. 30). 
Scheepstra, A. J. M. S., Nakken, H. \& Pijl, S. J. (1999). Contacts with classmates: The social position of pupils with Down's syndrome in Dutch mainstream education. European Journal of Special Needs Education, 14(3), 212-20.

Tanaka, Y. (2017). Myanmar no kyouiku: Gakkou seido to kyouiku katei no genzai, kako, mirai [Education in Myanmar: The present, past, and future of the school system and curriculum]. Tokyo: Akashi Shoten.

Tonegawa, Y. (2019). Policy and practice of 'inclusive education' in Addis Ababa, Ethiopia: An analysis from the perspectives of teachers and parents of children with disabilities. Nilo-Ethiopian Studies, 24, 31-45.

UNESCO Institute of Statistics (UIS) (n.d.). National monitoring; total net enrolment rate by level of education. Retrieved 12 December, 2020 from http://data.uis.unesco.org

UNESCO \& Ministry of Education and Science Spain (MoES) (1994). The Salamanca statement and framework for action on special needs education. Adopted by the World Conference on Special Needs Education, Salamanca, Spain.

UNESCO (2009). Towards inclusive education for children with disabilities: A guideline. Bangkok: UNESCO Bangkok.

UNESCO (2014). Education for all 2015 national review: Myanmar, National EFA Review Report, The Government of the Republic of the Union of Myanmar, Ministry of Education.

UNICEF (2016). Situation analysis of children with disabilities in the Republic of the Union of Myanmar. Yangon: UNICEF Myanmar.

United Nations (UN) (2019). Disability and development report: Realizing the sustainable development goals by, for and with persons with disabilities 2018. New York: United Nations.

United Nations (UN) (2006). United Nations Convention on the Right of Persons with $\begin{array}{lllll}\text { Disabilities. } & \text { Retrieved } & 09 & \text { February, } & 2021\end{array}$ https://www.un.org/esa/socdev/enable/rights/convtexte.htm

United Nations (UN) (n.d.). Sustainable development. Department of Economic and Social Affairs, Retrieved 08 February, 2021 from https://sdgs.un.org/goals/goal4

Warnock, M. \& Norwich, B. (2010). Special educational needs: A new look. London: Bloomsbury.

World Federation of the Deaf (WFD) (2008). WFD position paper on inclusive education. Approved by WFD Board on 10 May 2018. 